\title{
LEGAL DIMENSION OF CIVIL SOCIETY ACTIVITIES (THE SOUTH PACIFIC EXAMPLE)
}

\author{
Joanna Siekiera \\ University of Bergen, Bergen, Norway
}

\begin{abstract}
Introduction: the significant impact of civil societies on regionalism processes worldwide should not be left. This comes from the fact that citizens are becoming increasingly aware of their rights, as well as any possible impact on their own nation or region by joint social activities. Moreover, in line with the expansion of human rights (here, we are talking about the third category, the so-called third generation of rights - social rights), citizens can participate in adoption of legal and political decisions also at the local level. They see themselves as ever-growing importance of players in regional management. The South Pacific, being relatively new region, is showing clearly the evidences of such civil social activities too. Methods: the methodological framework for this article is a set of methods of scientific knowledge, among which the main ones are the methods of public policy, analysis, and the formal legal method. Results: the article, presenting knowledge which is not enough studies in the European scientific literature will bring the legal dimensions of regionalism, as well as the actual functioning of the civil society organizations' activities. To do so, it is necessary to describe some aspect of the Pacific cooperation in its formal, as well as informal methods and paths. Conclusions: the role and importance of CSO, as well as their great contribution to economic, social, cultural and political development, have long been known and appreciated globally. According to the United Nations, the role of social organizations in the process of regionalism in the South Pacific is crucial and necessary.
\end{abstract}

Key words: civil society, civil organizations, CSO, Pacific, South Pacific.

Citation. Siekiera J. Legal Dimension of Civil Society Activities (The South Pacific Example). Legal Concept, 2019, vol. 18, no. 4, pp. 159-165. (in Russian). DOI: https://doi.org/10.15688/lc.jvolsu.2019.4.22

УДК $341.1 / .8$

ББК 67.91
Дата поступления статьи: 11.09.2019 Дата принятия статьи: 05.10.2019

\section{ПРАВОВОЙ АСПЕКТ ДЕЯТЕЛЬНОСТИ ГРАЖДАНСКОГО ОБЩЕСТВА (НА ПРИМЕРЕ ГОСУДАРСТВ ЮЖНОЙ ЧАСТИ ТИХОГО ОКЕАНА)}

\author{
Джоанна Сиекиера \\ Бергенский университет, г. Берген, Норвегия
}

\begin{abstract}
Введение: гражданское общество значительно влияет на процессы регионализма во всем мире. Это связано с тем, что граждане все больше осознают свои права, а также любую возможность воздействовать совместной общественной деятельностью на регион или нацию. Более того, в связи с расширением прав человека (здесь речь идет о третьей категории, так называемом третьем поколении прав - социальных правах) они могут участвовать в принятии правовых и политических решений и на местном уровне. Граждане видят в себе постоянно растущее значение игроков в региональном управлении. Южная часть Тихого океана, будучи относительно новым регионом, также наглядно демонстрирует свидетельства такой гражданской общественной деятельности. Методы: методологической основой данной статьи является совокупность меخे тодов научного познания, среди которых - публичная политика, анализ и формально-правовой метод. Результаты: в статье представлены знания, которые недостаточно изучены в европейской научной литературе, приведены правовые аспекты регионализма, а также фактическое функционирование деятельности организаций гражданского общества. Описаны некоторые аспекты Тихоокеанского сотрудничества в его формальных, а также неформальных способах и путях развития. Выводы: роль и значение ОГО, а также их большой
\end{abstract}


вклад в экономическое, социальное, культурное и политическое развитие давно известны и высоко ценятся во всем мире. По мнению Организации Объединенных Наций, роль общественных организаций в процессе регионализма в южной части Тихого океана является необходимой и решающей.

Ключевые слова: гражданское общество, гражданские организации, ОГО, Тихий океан, Южная часть Тихого океана.

Цитирование. Сикира Дж. Правовой аспект деятельности гражданского общества (на примере государств Южной части Тихого океана ) // Legal Concept = Правовая парадигма. -2019. - T. 18, № 4. - C. 159-165. - DOI: https://doi.org/10.15688/lc.jvolsu.2019.4.22

\section{Introduction}

The subject of this article is the impact of the formal regional policy of the states in the South Pacific on the processes of Pacific regionalism. Such regional cooperation in turn affects the functioning of the regional communities in its international and national significance. It has to be noted here that the immense distances between the islands of a given state does not help either in this highly complex procedure of harmonizing region. The catalogue of the regional policy methods, which are used by three international legal actors in the Pacific (independent states, dependent territories and associated states) is multifaceted and consists of both formal, legal tools, as well as nonbinding soft law methods of cooperation. When it comes to the latter group, here the CSO - civil society organizations take advantage. Pacific regionalism is also characterized by a variety of umbrellas under which some entities are using it. Most importantly, we have here the global actors, like the United Nations with its regional organs ${ }^{1}$, intergovernmental organizations (IGO) ${ }^{2}$, intergovernmental with some characteristics of the sui generis institution, as well as, however to a lesser extent, non-governmental organizations (NGO) and CSOs.

The significant impact of the civil societies on regionalism processes should also be pointed out at the beginning of this article. This is due to the fact that citizens are becoming increasingly aware of their rights and their possible impact on own nation or region. Moreover, in line with the expansion of human rights (we are talking about the third category, the so-called third generation of rights ${ }^{3}$ ), citizens can participate in adoption of political and legal decisions also at the local level. Finally, at the beginning of the $21^{\text {st }}$ century, people see themselves as having ever-growing importance in regional management. The very term "civil society" is relatively new in both social sciences, as well public policy. In these disciplines this term can be understood as: "Voluntary associations $<\ldots>$ trying to shape norms along with policies regulating public life in the social, political and economic dimensions, as well as in environmental one. Currently, the scope of management has gone beyond local matters for the benefit of the world" [4, p. 18].

$\mathrm{CSO}$, becoming a new international entity has introduced the concept of "we people of the world". Regarding regionalism, it is important to be aware that any decision-making process nowadays is being guided by private, as well as public entities, which are not anymore "state actors". Therefore more often we can observe the huge involvement of so-called NSA - non state actors in both international relations, as well as international law as such. At their beginnings, regional communities, which had then evaluated into separated geopolitical units of regions, were created on the basis of shared values and uniqueness of the supranational society of citizens [4, p. 58]. However, CSO's tremendous commitment was often overlooked in the debate on new regionalism $[4$, p. 66]. This article is a modest try to change that, as well as to bring closer the specific of the civil society in the Pacific for the European reader.

\section{Civil society in the Pacific}

The principle of good governance in public policy is also connected with the civil society activities. It has its own dimension in providing integration in the Pacific too. "Good governance Pacific style" is an Australian government program aimed at deepening cooperation with PIC - Pacific island counties ${ }^{4}$. However, it was initiated by the NGO sector cooperating with civil society partners. These two sides began to look for more effective methods of implementing legal and economic, as well as strongly needed 
administrative reforms directly in the public sector. Here we can observe the standard down-rooted initiative, which was launched by the CSO, which were able to present the expected and highly detailed outcome of the state's intervention. The proposed good governance standards incorporate activities that emphasize strengthening of the position of civil society and human rights in the Pacific region. The most common and effective forms of Australian good governance are until now public consultations, relevant development subsidies and aid programs that have become an integral part of the PIC nations in the two first decades of the $21^{\text {st }}$ century [17].

Activities of CSO are widely visible both at the regional organizations level, as well as in each Pacific internal policy. Very often those two spheres of policy are closely connected and affecting each other. One of the latest examples of such mutual interaction, with the additional civil society engagement, was the Fiji's politics. Pacific Island Forum (PIF) is one of the most important and numerous in the term of its membership across the Pacific Ocean. New regional policy introduced by PIF after 2009 was a waking up call of the government in Suva, capital of Fiji. After another coup d'état held by the military authorities, other Pacific states were unwilling to continue any form of cooperation with Fiji. The Fijian suspension from the rights of the full member was fortunately used as motivation by the local politicians. Democratic reforms were initiated by a regional activist and later prime minister and president, Josio Voreqe Bainimaram, commonly known as Frank Bainimarama. This widely respected and charismatic politician (nomen omen former commander of the coup d'état), contributed to build important position of Fiji in the region and globally. The Fijian government was one of the first across the Pacific to introduce the principle of involving civil society into the decision-making procedure. $\mathrm{He}$ has invited officially representatives of private sector, as well as other NSA officials to the negotiation table. Such activity, having no previous precedence, was already called by the scientist, politicians and journalist as a new type of "network diplomacy", launched in the perfect moment of the Pacific regionalism [6, p. 6-7].

Also, the most important joint military regional intervention in the Pacific was launched by the civil society. The Solomon Islands, until
1978 dependent on Great Britain, have entered the history of Pacific regionalism by conducting an unprecedented armed action on its territory. The participation of civil society in peace-building was for the first, and for the last so far, shown through the Regional Assistance Mission to the Solomon Islands (RAMSI). This local initiative was formed as an answer to the internal crisis: long years of ethnic violence, abuse of power of subsequent governments, widespread crime and a minimal economic base, which all have weakened stability of the state. The British way of exercising power, as well as the European value of so-called national state was important and therefore sanctioned by the British, but neglected by the islanders, as an imposed, colonial influence. The Solomonians could not and were in fact not able to understand its basic concept, as they were so much varied ethnically and economically. For two decades, the newly created international unit did not show any national ties, hence public policy at the regional and national level was poorly conducted. On the one hand officials and politicians were unskillful, and above all they performed their duties unlawfully, on the other hand - citizens did not grant any extend of authorization to persons exercising power on their behalf. This vicious circle led to a state of fact where police were unable to guarantee compliance with law and order, becoming part of the unlawful state system [9]. Then in 2003, Prime Minister Sir Allan Kemakeza, aware that the Solomon Islands were becoming a failed state, asked the Australian government for intervention. Australia, giving a 95\% financial and military contribution, has organized a regional stabilization mission along with 14 PIC. As a result of the activities carried out under the RAMSI mission, the foundations for the long-term stability, security and prosperity of the Solomonians have been sanctioned [13]. That would not be possible without the prior reports and publicizing the poor state of the country by CSO.

Regionalism, which is very often forgotten, assumes the processes of creating a common platform, controlled by state authorities, including new IGOs, and the supranational network of CSOs, pursuing common goals, which articulate and develop a common identity - regional identity [1, p. 1001-1002]. Another factor that has been already mentioned in this article is noticeable 
improve of governance due to close collaboration with the civil society groups and other NSAs which are essentially interested in developing Pacific islanders' living conditions [2, p. 46-47.]. It has to be underlined that those civil society networks function everyday among the inhabitants of islands, in the suburbs, remotest villages, as well as big capital cities. They are therefore the most informed, having information, analysis and data hard to get by the officials working in the parliament on the daily basis. Such social groups, jointly called CSO, are also organizations of private investors, scientists or expert groups, as well as religious associations, mainly associated with different churches, which in fact possess causative power for deeper (that is closer to people) and binding (explaining and justifying) harmonization of the Pacific region. Here the comment is needed, as the national values of the Pacific peoples, as well as Australians and New Zealanders, arise from the Anglo-Saxon mentality combined with the Protestant denomination that mandate the help for the weak, as well as obligatory wealth sharing $[8$, p. 224].

\section{Formalization of civil society activities}

A characteristic feature of young Pacific regionalism is the high participation and governmental support, in both financial and structural terms, of CSOs. The involvement of the civil structures in the complex process of the regional is launched mutually on both national and local levels. Therefore, as It was already mentioned, the activities of CSO affect each other, despite of their internal or external cause. development of prosperity at the national level, but also of the entire united region. The Pacific Regional Non-Governmental Organizations Alliance (PRNGO Alliance) is a grouping of 14 regional NGOs, having members' networks located in 10 PIC [12]. Along with the Alliance, over 37 groups operating within the NSA and CSO conducted social consultations and analyzes of the current and required legal situation in the Pacific. Their joint work is available in the document called the Pacific Plan [15]. This non-binding political declaration is a prospect for the new millennium signed in 2007 by the PIF members. Here we can observe the strong importance of a multi-actor and multi-sector network of regional intergovernmental agencies, which had based their prognosis on on links with churches, NGOs and CSOs.

In many cases, those were CSO that initiated dialogue and led to effective resolution of regional issues in the Pacific. The vivid illustrations of this state of affairs could be the activity of the Nuclear Free and Independent Pacific movement in raising public awareness regarding the effects of nuclear tests in the 1970s. That is turn led to signing the Treaty of Rarotonga (South Pacific Nuclear Free Zone Treaty from 6 August 1985). Subsequently, the Pacific women's organizations managed to publicize the issue of gender equality, talking out loud about domestic violence and sexual abuse at home and workplace [16]. Those questions were previously taboo, and no government in the Pacific, composed mainly by men, were willing to touch upon them. Finally, women's unions and church institutions were also active long before the peacekeeping intervention in conflicts in New Caledonia, Bougainville (autonomous province in Papua New Guinea, PNG) and the Solomon Islands. However, it was only after several decades that government representatives and private sponsors began to support social initiatives not only through political statements, but also through specific, permanent and cost-effective regional mechanisms [6, p. 65-66].

The role and importance of CSO, as well as their great contribution to economic, social, cultural and political development, have long been known and appreciated globally. According to the United Nations Development Program, the role of social organizations in the process of regionalism is to fulfill three functions. The first function is to provide basic public services such as elementary education, healthcare, drinking water supply and sanitation, as well as to facilitate participation of local communities in budget planning. The second function is to defend human and citizen rights of the island nations. Finally, the third function is to provide special protection to marginalized social groups by providing them advisory services and legal support [6, p. 66-67].

In recent years, there can be observed increase in the number and diversity of NSA, NGO and CSO across the Pacific basin. These institutions are gradually more taking on the role of associate members, observers or dialogue partners in formal IGOs, which was originally reserved only for the sovereign states. This does 
demonstrate the new architecture of international relations in the South Pacific, where decisionmaking processes are no longer determined by a strict group of PIC, but institutions are finally using soft law instruments launched by CSO. Interestingly, also territorial units aspiring to the group of independent states rely strongly on international support and recognition from NGOs. We are talking primarily about New Caledonia, West Papua in Indonesia, Bougainville, Tahiti belonging to French Polynesia, as well as to a lesser extent (yet) the American state of Hawaii. These entities see in the activities of the NSA and CSO quick, cheap and very effective help in publicizing their right to self-determination, and then promoting their recognition as future states on the international forum.

What is characteristic, but also defective, for regionalism in the Pacific, is the fact that integration initiatives are initiated not by all or at least a large part of PIC or their CSO, but above all by Australia or New Zealand. Because of the controversy expressed by civil society organizations, the Pacific politicians and decision makers accuse the governments in Canberra and Wellington of exploiting island states through expanding their sales markets [10]. This only confirms the thesis that the primary and still valid reason for regional cooperation in the Pacific Ocean are financial issues, not political and humanitarian development. Cost-effectiveness, or rather "unprofitability" as most island microstates perceived it, of initiation and subsequent completion of regionalism projects fundamentally affects passivity in the implementation of regional policy. In turn, the governments in Canberra and Wellington see in their high, unrivaled activity an opportunity to acquire potential capital bases. These bases are still susceptible to control or even strong external influences from the Pacific Rim states, like Chine, Russia and the USA. Another shortcoming explaining the negligible down rooted initiatives in the South Pacific is the lack of unity of general regional interests and mutual long-term development strategy, as well as conflicts for leadership in three subregions (Polynesia, Micronesia and Melanesia) [7, p. 469].

Finally, in 2013, there came an urgent necessity to amend the Pacific Plan, document signed by the PIG member states. Unsurprisingly, also this time CSO were asked to help out. The civil consultations were introduced by PNG Prime Minister, widely respected Pacific leader Mekere Morauta. In his work, eventually amounted to two volumes of text, he was using social consultations with CSO, NGO representatives, universities, regional agencies, as well as strategic partners and private development institutions [11, p. 10]. In his report he stated that over the years, since the adoption of the Plan, the Pacific region had undergone significant evolution, while approach to regionalism had also changed [11, p. 44]. Mekere Morauta also suggested institutional and substantive changes in the further functioning of the Plan by proposing creation of a new framework for regional cooperation that would meet the political principles of regionalism in international dialogue, where CSO had to have their own and permanent place. It was the beginning of creation of a new strategic plan in 2014, which was called the Framework for Pacific Regionalism [5].

The full implementation of the Framework, which has replaced the Pacific Plan, must be done with support, dedication and awareness of the islanders. Hence, PIF members constantly seek support and actual help in CSO, private sector, regional IGOs, media and development partners. Organization's values, such as respect for integrity of the ocean and island resources, diversity and heritage of the Pacific people, good governance, compliance with democratic standards of governance, rule of law, promotion of human rights, equality of the Pacific population and finally open intra-regional relations are to contribute to achieving the new goals of PIF. It all cannot be successful accomplished without the soft power of civil society [5].

Finally, the latest IGO, Pacific Island Development Forum (PIDF), established in 2015, is open not only to the sovereign states, but its constituting treaty enumerates the possible membership. In its article 7, the Charter of the Pacific Islands Development [3]. Thus, the membership is open to the Pacific islands, as well as any Pacific organizations willing and being able to fulfill the rights and obligations arising from the PIDF membership. Besides 17 founding countries, there are two regional organizations: the Pacific Islands Association of Non-Governmental Organizations and the Pacific Islands Private Sector Organization. Without going into details, the PIDF Charter is often called as the pacific 
constitution, as some hope was given since establishment of this IGO [14, p. 317-328].

\section{Conclusion}

The article has presented significant impact of civil societies on regionalism processes in the South Pacific, between the states and other non sovereign entities in Oceania. Citizens across the globe are becoming more aware of their rights, as well as gain political and legal impact on own nation or region. As it was describes, citizens participate in adoption of regional norms both at the internal and external, regional level. They see themselves as ever-growing importance of players in regional management, but more importantly, they are asked to join the formal IGO consultations for the good of the whole community. The South Pacific, being relatively new region, is showing clearly the evidences of such civil social activities. too. The Pacific cooperation is varied, as the region itself is diverse. Therefore $\mathrm{CSO}$ use both formal, binding methods of hard law, like treaties, membership in intergovernmental organizations, as well as informal, soft law paths. It can be said that the role and importance of $\mathrm{CSO}$, as well as their great contribution to economic, social, cultural and political development is crucial and necessary. Very often politicians and decisionmakers would not be able to achieve their goal of regionalism, without valuable, detailed and actual information gathered by the civil social organizations.

\section{FOOTNOTES}

${ }^{1}$ United Nations Economic and Social Commission for Asia and the Pacific (ESCAP), amounted to 62 members, is the most comprehensive regional agency in the $\mathrm{UN}$ family.

${ }^{2}$ The institutional basis of regionalism in the South Pacific is indeed the activity of intergovernmental international organizations. According to the author's own calculations, there are over 30 regional organizations and 15 or so informal regional forums in the Pacific basin. What is important here is the fact that any Pacific organizations very often change their names quite, which impact in turn the status' scope of territorial membership and activity. It was in the case of the Pacific Regional Environment Program which was renamed from the South Pacific Regional Environment Program. Also, regional IGO are absorbed by other institutions and do not function under the same name anymore, like it was with the South Pacific Board of Educational Assessment, which was incorporated into the Secretariat of the Pacific Community.

${ }^{3}$ First category of human rights were the political and citizen rights, while the second - the social and economical ones. Third category of human rights is connected with the joint, common for the society, set of rights which are given for the groups of people, varied communities.

${ }^{4}$ In accordance with the Montevideo Convention on rights and duties of the states from 1933, we cannot call any international entity on the Pacific as a sovereign state. Therefore the author is intentionally using a term "country", which has a broader scope.

\section{REFERENCES}

1. Acharya A., Asia Is Not One. The Journal of Asian Studies, 2010, vol. 69, no. 4, pp. 1001-1002.

2. Australian Agency for International Development, Pacific 2020: Challenges and Opportunities for Growth. Canberra, Australian Government, May 2006, pp. 46-47.

3. Charter of the Pacific Islands Development Forum from 4 September 2015. PIDF, Suva.

4. Cooper A.F., Hughes Ch.W., De Lombaerde P., eds. Regionalisation and Global Governance: the Taming of Globalisation? New York, Abington, Routledge, 2008. $272 \mathrm{p}$.

5. Framework for Pacific Regionalism Pacific Islands Forum Leaders, July 2014. PIDF, Suva.

6. Fry G., Tarte S., eds. The New Pacific Diplomacy. Canberra, ANU Press, 2015. 305 p.

7. Fry G. Regionalism and International Politics of the South Pacific. Pacific Affairs, 1981, vol. 54, no. 3, pp. 455-484.

8. Kozielski P., Australia i jej rola $w$ ksztaitowaniu procesów integracyjnych w obszarze Azji Pacyfiku, Warsaw, CEDEWU Publ., 2015. 350 p.

9. Merrell S., Seminar: RAMSI and the Solomon Islands: Nationalism vs. Regionalism. Victoria University, Melbourne 8.04.2010.

10. PACER \& PICTA. Bilateral.org. URL: https:/ /www.bilaterals.org/?-PACER-PICTA-\&lang= (Accessed 25 August 2019).

11. Pacific Plan Review 2013: Report To Pacific Leaders. Vol. 1, Suva, Fiji, Pacific Islands Forum Secretariat, p. 10.

12. PRNGO Alliance. URL: https:// www.pasifikarising.org/prngo-alliance (Accessed 25 August 2019). 
13. RAMSI Mission. URL: https://www.ramsi.org (Accessed 25 August 2019).

14. Siekiera J., Regionalna Konstytucja Integracja Wysp Pacyfiku Południowego. KawaMarszałek J. ed. Współczesne problemy Azji $i$ Pacyfiku, Toruń, Adam Marszałek Publ., 2017, pp. 317-328.

15. The Pacific Plan for Strengthening Regional Cooperation and Integration, November 2007. PIDF, Suva.
16. Tonga government steps away from CEDAW ratification. Radio New Zealand. URL: http:// www.radionz.co.nz/international/pacific-news/ 283057/tonga-government-steps-away-from-cedawratification (Accessed 25 August 2019).

17. Wendt N. Australia's Role in the Region Preventing Failed States. Conference Human Rights: A Pacific Agenda - Partnership and Perspectives. Inaugural Amnesty International Australia Human Rights, 4-5 September 2004 Brisbane.

\section{Information about the Author}

Joanna Siekiera, Doctor, Postdoctoral Fellow, Faculty of Law, University of Bergen, Magnus Lagaboetes Plass, 1, 5010 Bergen, Norway, joanna.siekiera@uib.no, https://orcid.org/0000-0003-0125-9121

\section{Информация об авторе}

Джоанна Сиекиера, доктор, постдокторант, юридический факультет, Бергенский университет, Магнус Лагаботес Пласс, 1, 5010 г. Берген, Норвегия, joanna.siekiera@uib.no, https://orcid.org/ 0000-0003-0125-9121 